\title{
Lecithins: A Food Additive Valuable for Antifungal Crop Protection
}

\author{
M. Jolly, R. Vidal and P. A. Marchand ${ }^{*}$
}

Institut Technique de l'Agriculture Biologique (ITAB), 149 rue de BERCY, F-75595 Paris CEDEX 12, France

\section{Corresponding Author}

P. A. Marchand

e-mail: patrice.marchand@itab.asso.fr

\author{
Article History \\ Article ID: IJEP0243 \\ Received in $11^{\text {th }}$ March, 2018 \\ Received in revised form $28^{\text {th }}$ July, 2018 \\ Accepted in final form $17^{\text {th }}$ August, 2018
}

\begin{abstract}
Lecithins area generic term to designate group of fatty substance in animal and plant tissues. Despite is low solubility in water, lecithin is an excellent emulsifier. It's used as a food additive for smoothing food textures. Lecithins are also described with plant protection capacity as fungicide. In order to confirm the utility of lecithins in crop protection, experimentations were developed by our institute. Fields trials were coordinated in France by the "HE" Casdar program between 2013 and 2016. The antifungal properties of lecithins were tested against mildews in organic and non-organic farms. Typical used concentrations of lecithins in water are from 75 to $200 \mathrm{~g} \mathrm{hl}^{-1}$ and amounts from $75 \mathrm{~g}$ to $2 \mathrm{~kg} \mathrm{ha}^{-1}$ for fungicide uses. Positive results conduct to legalize agricultural application. Lecithins are now approved as basic substance with fungicide properties in EU.
\end{abstract}

Keywords: Lecithins, fungicide, biopesticide, downy mildew, powdery mildew

\section{Introduction}

Lecithin is a generic term to designate any group of yellowbrownish fatty substances occurring in animal and plant tissues composed of phosphoric acid, choline, fatty acids, glycerol, glycolipids, triglycerides, and phospholipids. Lecithin has emulsification and lubricant properties, and is a surfactant (FAO, 2007). Lecithins are used for applications in human food, animal feed, pharmaceuticals, paints, and other industrial applications (Szuha, 1989; EU, 2017).

Outside from the food environment, considering its properties, few people tried to use it as plant protection product (Dayan, 2009) and some patent were launched early (Ghyczy et al., 1987) but level of efficacy were lower than conventional fungicide. Today, low concern biorationals are needed to replace chemical for different reasons (environment contaminations, metabolite considerations, resistances, withdrawal...) thus even less efficient crop protection products are gaining interest (Bohinc, 2015).

\section{Materials and Methods}

\subsection{Fields experiment and trial}

Between 2013 and 2015 in France, field trials were conducted in the " $\mathrm{HE}$ » Casdar program. Lecithin was tested as fungicide against grape downy and powdery mildew (Plasmoparaviticola, Erysiphenecator) in vineyard (organic and non-organic farms) (Vidal, 2016).Previous experimental lecithin studies validated natural uses. Many uses of the product are now affordable and effective for plant protection. Clearly, this substance is fully within the scope of the Recital 18 of Regulation (EC) No 1107/2009 concerning food status and utility in crop protection. Regulatory expertise on lecithin as a natural substance allows the development of a new alternative to the use of pesticides for plant protection. Included in this protection is the formation of a physical barrier. Lecithins are indeed non-biocidal; it prevents the spread of fungal diseases without killing the fungi. This information is significant, considering the importance of reducing pesticides toxicity while meeting the expectations of organic producers (Lichtfouse, 2013).

\subsection{Ecotoxicological assessments}

According to the EU Department of health and human service, lecithinsare authorized for use in food with no limitation other than current good manufacturing practice. Lecithinsare affirmed as safe for food use by the Office of Food Additive Safety and are approved as a food additive under other internationally recognized standards (DHHS, 2012). Lecithinsare also classified (Pino, 2013) as "Generally Recognized As Safe" (GRAS). Lecithinsare practically nontoxic to aquatic organisms. Should lecithin be released into the environment, it is considered readily biodegradable. Lecithins are not expected to be persistent norbioaccumulative (DuPont, 2012). Moreover, lecithinsarealso bee food products (Feo, 1957) and no adverse effect is described in literature (PAN 
Pesticides Database, 2017).

\subsection{Recipes}

Solutions in water were tested and defined during field trials or identified from the literature and checked. Whenever water is mentioned in these tests clearly natural spring or cold rain water is used. Typical used concentrations of lecithin in water are from 75 to $200 \mathrm{~g} \mathrm{hl}^{-1}$ and amount from 0.075 to $2 \mathrm{~kg} \mathrm{ha}^{-1}$ for fungicide use (Marchand, 2016).

\section{Results and Discussion}

\subsection{Plant protection products with non-biocidal mode of action}

Lecithin solution is intended for field use as fungicide on vineyards, fruit trees, vegetable gardening and ornamentals (Misato et al., 1977; Trdan et al., 2008). In the field concentrations of lecithin between 0.01 and $0.1 \%$ provide protection between 25 to $30 \%$ against Plasmopara viticola on grapevines. However, a lower concentration of $0.05 \%$ is more effective than in vitro assays at higher concentrations $(0.5 \%)$ (Aveline et al., 2013).

Statistical difference with control (no treatment or water control) is positive for all concentrations ( 0.01 to $0.2 \%$ ) with foliar disks. An additional field efficacy trial demonstrated a reduction of powdery mildew contaminations in vineyards, which supports the existing registration of lecithin in Switzerland and the use at 75-200 $\mathrm{g} \mathrm{hl}^{-1}$ concentration.The activity of lecithins as antifungal substance is done by direct contact (Castillo, 2012); lecithins inhibit mildew spores germination.

\subsection{Lecithin classified as basic substance}

Lecithin is therefore a natural product of little concern that triggers and amplifies the plantsdefences as elicitor. This product is operational in Europe and is part of the substances called base substance. The basic substances are substances of natural origin (Marchand, 2015; 2016) ultimately come from a food product. Lecithins are a foodstuff (EC, 2002) thus intrinsically considered as basic substance (EC, 2009). The low negative impact of the constituents of lecithins on the environment due to their vegetal origin and the lack of health issues ledto an easy definition of Maximum Residue Limits (MRL) on agricultural crop production. Lecithins aregranted without MRLs. Moreover, most basic substances as lecithinsare allowed in organic farming (Marchand, 2017a). Basic substance may be used around the world for their initial uses and as biopesticides (Marchand, 2017b) after submission to local pesticide regulations.

\subsection{Discussion}

In the EU pesticide database, application of lecithin on plants is described: the method kind for lecithin is spray applicationfor all applications.

On fruit trees (Apple, Malus pumila and Peach, Prunus persica trees) against powdery mildews (Podosphaera leucotricha) and peach leaf curl (Taphrina deformans), lecithin is applied from the growth stage when the end of leaf bud swelling to fruits about $90 \%$ of their final size ( $\mathrm{BBCH}$ stage 03 to 79). The product can be used 3 to 12 times with an interval of 5 days between each application. The application rate per treatment is $75 \mathrm{~g} \mathrm{hl}^{-1}$ of lecithin with water from 500 to $1000 \mathrm{I} \mathrm{ha}^{-1}$. The substance is therefore applied from 375 to $750 \mathrm{~g} \mathrm{ha}^{-1}$.

On gooseberry (Ribes uva crispa) against powdery mildews (Microsphaera grossulariae), lecithin is applied from the growth stage when the start of leafs development to the increase in intensity of cultivar-specific colour (BBCH 10 to 85). The product can be used 2 to 4 times with an interval of 5 days between each application. The application rate per treatment is $200 \mathrm{~g} \mathrm{hl}^{-1}$ of lecithin with water from 500 to $1000 \mathrm{I} \mathrm{ha}^{-1}$. The substance is therefore applied from 1000 to $2000 \mathrm{~g} \mathrm{ha}^{-1}$.

On market vegetables gardening like cucumber (Cucumis sativus) against powdery mildew (Podosphaera xhantii), lecithin is applied from the growth stage when cotyledons are spread out (BBCH stage 10 to 89). The product can be used 2 to 6 times with an interval of 5 days between each application. The application rate per treatment is $150 \mathrm{~g} \mathrm{hl}^{-1}$ of lecithin with water from 1000 to 1500 I ha-1. The substance is therefore applied at $1500 \mathrm{~g} \mathrm{ha}^{-1}$ rate.

On lettuce (Lactuca sativa) against Erysiphe cichoracearum, lecithin is applied from the growth stage whencotyledons spread, apical vegetative point or initials of the first true visible leaves to $50 \%$ of the fruits are ripe or $50 \%$ of the seeds have their typical colour and are hard and dry (BBCH stage 10 to 89). The product can be used 2 times with an interval of 7 days between each application. The application rate per treatment is $150 \mathrm{~g} \mathrm{hl}^{-1}$ of lecithin with water from 1000 to $1500 \mathrm{I} \mathrm{ha}^{-1}$. The substance is therefore applied at $1500 \mathrm{~g} \mathrm{ha}^{-1}$ amount.

On mashes (Valerianella locusta) against Erysiphe polyphaga, lecithin is applied from the growth stage when cotyledons spread, apical vegetative point or initials of the first true visible leaves to $50 \%$ of the fruits are ripe or $50 \%$ of the seeds have their typical colour and are hard and dry cotyledons spread, apical vegetative point or initials of the first true visible leaves to $50 \%$ of the fruits are ripe or $50 \%$ of the seeds have their typical colour and are hard and dry (BBCH stage 10 to 89). The product can be used in only one application. The application rate per treatment is $150 \mathrm{~g} \mathrm{hl}^{-1}$ of lecithin with water from 1000 to $1500 \mathrm{I} \mathrm{ha}^{-1}$. The substance is therefore applied 1500 $\mathrm{g} \mathrm{ha}^{-1}$ rate.

On Tomato (Lycopersicum esculentum) against tomato blight (Phytosphtora infestans), lecithin is applied from the growth stage whencotyledons spread (BBCH stage 10 to 89). The product can be used 2 to 6 times with an interval of 7 days between each application. The application rate per treatment is $150 \mathrm{~g} \mathrm{hl}^{-1}$ of lecithin with water from 1000 to $1500 \mathrm{I} \mathrm{ha}^{-1}$. The substance is therefore applied $1500 \mathrm{~g} \mathrm{ha}^{-1}$ rate.

On Endives (Cichorium endiva L.) against fungus (Alternaria cichorii), lecithin is applied from the growth stage when 
cotyledons spread, apical vegetative point or initials of the first true visible leaves to $50 \%$ of the fruits are ripe or $50 \%$ of the seeds have their typical colour and are hard and dry $(\mathrm{BBCH}$ stage 10 to 89). The product can be used 2 to 6 times with an interval of 7 days between each application. The application rate per treatment is $150 \mathrm{~g} \mathrm{hl}^{-1}$ of lecithin with water from 1000 to $1500 / \mathrm{ha}^{-1}$. The substance is therefore applied at $1500 \mathrm{~g} \mathrm{ha}^{-1}$ rate.

On ornamentals (especially roses), against powdery mildews and other fungal diseases, lecithin is applied from the growth stage when cotyledons spread (BBCH stage 10 to 89). The product can be used 3 to 12 times with an interval of 5 days between each application. The application rate per treatment is $75 \mathrm{~g} \mathrm{hl}^{-1}$ of lecithin with water from 100 to $300 \mathrm{I} \mathrm{ha}^{-1}$. The substance is therefore applied from 75 to $225 \mathrm{~g} \mathrm{ha}^{-1}$.

On grapevine (Vitis vinifera) against powdery mildews (Plasmopara viticola and Erysiphe necator), lecithin is applied from the growth stage when the first leafs spread out and are away from shoot to the ripening (BBCH stage 11 to 85$)$. The application rate per treatment is $75 \mathrm{~g} \mathrm{hl}^{-1}$ of lecithin with water from 100 to $300 \mathrm{I} \mathrm{ha}^{-1}$. The substance is therefore applied from 75 to $225 \mathrm{~g} \mathrm{ha}^{-1}$.The minimum pre-harvest interval between the treatments is 5 days except for grapevine (30 days).

\section{Conclusion}

Lecithin is a foodstuff classified as food additive. In order to decrease the amount of xenobiotic pesticides released into the environment, adjuvant based on renewable sources like lecithin are requested. Lecithins can therefore be used as an antifungal biorationalpesticide(Bohinc, 2015). Lecithinsare applied as a contact product to reduce the production of fungal spores by activation of plant defences as well as direct effect on spore germination. It is an effective fungicide that can be used on fields in fruit tree, gooseberry, market vegetables, lettuces, mashes, tomatoes, endives, grapevines and ornamentals (EU pesticide database, 2017). Lecithinsare officially acknowledged as fungicide in organic farming at EU level by the common regulation (EC) No889/2008 in Annex Ilas basic substance (EU, 2016).

\section{Further Research}

In addition to known and approved fungicidal effect,lecithin is a component of insecticidal products as lysolecithin (Taylor, 2004). Lecithin is also used in post-harvesttreatments in co-application with fludioxonil as fungicide (Schirra, 2009).Furthermore, the addition of lecithin to eugenol solutions eliminates the phytotoxic effect of eugenol at high temperature, triggering a better activation of eugenol against the pathogensforapple postharvest protection (Amiri, 2008). Furthermore, some research should be done to be able to expand uses to other fungal diseases like gray (Botrytis cinerea) or blue (Penicillium spp.) moldor as described lately (Lachhab 2015, Romanazzi, 2016).

\section{Acknowledgment}

This work was made possible by public funding: investigation project about approval at EC regulation 1107/2009 was initially funded by French Ministry of Ecology-DGPR (Direction Générale de la Prevention de Risques) (CP ITAB PNPP V14 26-11-10, 2010-12) and field trials (Casdar HE) by French Ministry of Agriculture (MAAF) DGER (Direction Générale de I'Enseignement et de la Recherche).

\section{References}

Anonymous, 2017. Available from: http://ec.europa. eu/food/plant/pesticides/eu-pesticidesdatabase/public/? event=activesubstance. ViewReview\&id=917Lecithins

Amiri, A., Dugas, R., Pichot, A.L., Bompeix, G., 2008. In vitro and in vitro activity of eugenol oil (Eugenia caryophylata) against four important postharvest apple pathogens. International Journal of Food Microbiology 126(1-2), 13-19.

Aveline, N., 2013. Tests in vitro HE (Huil esessentielles) vs. mildiou de la vigne [In vitro tests of E.O. (essential oils) vs. downy mildew]in Research Program CADAR HE (Huiles Essentielles). Technical report. Institut Français de la Vigne et du Vin, Blanquefort, France, 1-17.

Bohinc, T., Znidarcic, D., Trdan, S., 2015. Comparison of field efficacy of four natural fungicides and metiram against late blight (Phytosphora infestans [Mont.] de Bary) on tomato. Horticulture Science 42(4), 215-218.

Szuha,B.F., 1989. Lecithins: Sources, Manufacture \& Uses, The American Oil Chemist's Society, Chapter 7, 109.

Castillo, F., Hernandez, D., Gallegos, G., Rodriguez, R., Aguilar, C.N., 2012. Antifungal Properties of Bioactive Compounds from Plants Fungicides for Plant and Animal Diseases in Fungicides for Plant and Animal Diseases www.intechopen.com Edited by Dr. Dharumadurai Dhanasekaran Part 4, 81-106.

Dayan, F.E., Cantrell, C.L., Duke, S.O., 2009. Natural products in crop protection. Bioorganic \& Medicinal Chemistry 17, 4022-4034.

DHHS, 2012. Memorandum Lecithin. Available from: http:// www.dhhs.tas.gov.au/news/2013/dhhs_annual_ report_2012-13.

EC, 2002. Commission Regulation No 178/2002, OJ L 31, of 1.2.2002, 1-24.

EC, 2008. Commission Regulation No 889/2008, OJ L 250, of 18.9.2008, 1-84.

EC, 2009. Commission Regulation No 1107/2009, OJ L 309 of 24.11.2009, 1-50.

EU, 2015. Commission Implementing Regulation No 1116/2015 of 9 July 2015 approving the basic substance lecithins, OJ L 182, of 10.7.2015, 26-28.

EU, 2016. Commission Regulation (EU) 2016/673 of 29 April, 2016 amending Regulation (EC) No 889/2008 laying 
down detailed Commission Implementing Regulation rules for the implementation of Council Regulation (EC) No 834/2007 on organic production and labelling of organic products with regard to organic production, labelling and control). 2016; L 116, of 30.4.2016, 8-22.

EU, 2017. EU Pesticides database http://ec.europa.eu/ food/plant/pesticides/eu-pesticides-database/ public/?event=homepage\&language $=E N$.

FAO, 2007. Lecithin INS No. 322 (i) http://www.fao.org/ ag/agn/jecfa-additives/specs/monograph4/additive250-m4.pdf

Feo, E.G., Feldman, E.D., Goetz, H.M., 1957. United States Patent. BEE FOOD COMPOSITION. Appl. No. 642, 958.

Ghyczy, M., Imberge, P.R., Wendel, A., 1987. United States Patent. Phospholipid compositions and their use in plant protection spray mixtures. Appl. No. 755, 967.

Lachhab, N., Sanzani, S.M., Bahouaoui, M.A., Boselli, M., Ippolito, A., 2016. Effect of some protein hydrolysates against gray mould of table and wine grapes. European Journal of Plant Pathology 144, 821-830

Lichtfouse, E., Schwarzbauer, J., Robert, D., 2013. Green materialsfor energy,products anddepollution in environmental chemistry for a sustainable world, Springer Ed., Vol 3, 1-476.

Marchand, P.A., 2015. Basic substances: an opportunity for approval of low-concern substances under EU pesticide regulation. Pest Management Science 71(9), 1197-1200. DOI:10.1002/ps.3997

Marchand, P.A., 2016. Basic substances under EC 1107/2009 phytochemical regulation: experience with non-biocide and food products as biorationals. Journal of Plant Protection Research 56(3), 312-318.

Marchand, P.A., 2017a. Basic Substances under EU Pesticide Regulation: an opportunity for Organic Production? Organic Farming 3(1), 16-19, DOI: 10.12924/ of2017.03010016.

Marchand, P.A., 2017b. Basic substance as renewable and affordable crop protection products.Chronicle of Bioresource Management, 1(2), 065-066.

Misato, T., Homma, Y., Ko, K., 1977. The development of a natural fungicide, Soybean lecithin. Netherlands Journal of Plant Pathology 83(Suppl. 1), 395-402. DOI: 10.1007/
BF03041455.

DuPont, 2012. MSDS Product Safety Summary Sheet Lecithin, DuPont ${ }^{\mathrm{TM}}$

PAN Pesticides Database as of 2017. Chemicals: Lecithin

Pino, O., Sanchez, Y., Rojas, M.M., 2013. Plant secondary metabolites as an alternative in pest management.l: Background, research approaches and trends. Rev. Proteccion Veg 28(2), 81-94.

Romanazzi, G., Feliziani, E., Landi, L., 2016. Preharvest treatments with alternatives toconventional fungicides to control postharvest decayof strawberry. ActaHorticulturae 1117. ISHS 2016. DOI 10.17660/ ActaHortic.2016.1117.19

Schirra, M., D’Aquino, S., Migheli, Q., Pirisi, F.M., Angioni, A., 2009. Influence of post-harvest treatments with fludioxonil and soy lecithin co-application in controlling blue and grey mould and fludioxonil residues in Coscia pears. Food Additives and Contaminants, 26, 68-72. http://dx.doi.org/10.1080/02652030802348080.

Taylor, W.G., Fields, P.G., Sutherland, D.H., 2004. Insecticidal components from field pea extracts: Soyasaponins and lysolecithins. Journal of Agricultural and Food Chem 52, 7484-7490.

Trdan, S., Znidaric, D., Vidrih, M., Ka, M., 2008. Three natural substances for use against Alternariacichorii on selected varieties of endive: antifungal agents, plant strengtheners, or foliar fertilizers? Journal of Plant Diseases and Protection 115(2), 63-68.

Vidal, R., 2016. Projet Casdar HE “Evaluation de l'interet de I'utilisationd'huilesessentiellesdans des strategies de protection des cultures" [Research program CASDAR "Evaluation of the benefits of using essential oils in strategies for crop protection]. CASDAR HE (huiles essentielles). Technical report. In: Proceedings of the Conference "Journees Substances Naturelles en Production vegetale". Institut Technique de l'Agriculture Biologique (ITAB), Paris, France, 26-27 April 2016, 45 pp. Available on: http://www.itab.asso.fr/publications/ jt-intrants2016.php [Accessed: June27, 2017]. 